Aim of the study: Informing cancer patients about various types of treatment and their adverse effects and communicating negative information is an important element of diagnostic and therapeutic procedures. Understanding the purpose of treatment and expectations, and socio-demographic factors in patients undergoing palliative chemotherapy because of lung cancer.

Material and methods: The study included 100 patients with lung cancer at the age of 40-80 years (mean 63.1) in the Oncology Center in Bydgoszcz in 2013-2014. The diagnostic survey method with the author's questionnaire was used.

Results: Forty-one percent of patients were convinced that the purpose of chemotherapy is to cure the disease. Both inhabitants of small towns (population below 50 thousand) and large villages $(p=0.09)$ were similarly convinced about the effectiveness of chemotherapy. Seventy-three percent of inhabitants of small towns and $79 \%$ of country dwellers $(p=0.005)$ thought that chemotherapy is aimed at improving the quality of life. Patients with very good economic conditions responded that chemotherapy is designed to improve the quality of life more often than those with good and bad economic conditions, $90 \%, 88 \%$ and $60 \%$, respectively $(p=0.001)$. With the increase in population the number of people who claimed that palliative chemotherapy prolongs their life increased, $71 \%, 77 \%$ and $90 \%$, respectively $(p=0.03)$.

Conclusions: The knowledge of patients with lung cancer about palliative chemotherapy is insufficient. Almost half of them do not understand the purpose of treatment and hope that chemotherapy will cure them of the disease. Most patients know that the aim of chemotherapy is to alleviate symptoms and improve quality of life and prolong their life. Half of the patients want to obtain information on treatment and half of them about life expectancy. Almost half of the patients feel stress and anxiety towards chemotherapy. Most patients do not use the help of a psychologist and do not feel such a need.

Key words: lung cancer, palliative chemotherapy, patients' expectations, treatment goals.

Contemp Oncol (Pozn) 2015; 19 (4): 333-337 DOI: $10.5114 /$ wo.2015.53249

\section{Understanding the purpose of treatment and expectations in patients with inoperable lung cancer treated with palliative chemotherapy}

\author{
Andrzej Nowicki ${ }^{1}$, Karolina Woźniak ${ }^{1}$, Małgorzata Krajnik ${ }^{2}$
}

${ }^{1}$ Department of Oncology Nursing, Collegium Medicum in Bydgoszcz, Nicolaus Copernicus University in Toruń, Poland

2Department and Unit of Palliative Care, Collegium Medicum, Nicolaus Copernicus University in Toruń, Poland

Lung cancer is a serious epidemiological problem, because by analyzing the structure of mortality it can be seen that it is the most common cause of cancer death among both men and women worldwide.

Often patients with advanced cancer insist on chemotherapy, believing that it may save their life. They have unrealistic ideas about what the effects of treatment with chemotherapeutic agents can bring because they do not realize themselves what is their effect. A large proportion of patients do not accept that they are in a critical condition and that medicine cannot give hope for a cure. Individualized patient care indicates its adaptation to the patient's personal goals. The focal point of this action should be conversation about prognosis and phases of treatment [1]. Therefore, it should provide the patients with information about the disease and getting to know about their expectations [2]. This approach helps to make informed decisions on treatment. In addition, socio-demographic factors such as age, sex, ethnic group, place of residence, marital status, race, and education may condition the understanding of the goal of palliative treatment of lung cancer using chemotherapy.

Understanding the purpose of treatment and expectations and socio-demographic factors in patients undergoing palliative chemotherapy because of lung cancer.

\section{Material and methods}

The study was conducted in the Department of Chemotherapy and Chemotherapy Outpatient Clinic at the Oncology Center in Bydgoszcz in 20132014. The study enrolled 100 consecutive patients, 34 women and 66 men, aged $40-80$ years (mean age 63.1) who underwent palliative chemotherapy (CHP) because of lung cancer where the expected survival period was longer than 6 months.

The method of diagnostic survey and adopted survey was used as a research technique in this work. Each person was informed about the study goal and how the questionnaire was designed before starting the survey. All respondents agreed to participate in the study. The questionnaire consisted of 18 closed-ended questions. Questions about socio-demographic data were included at the beginning of the questionnaire. The remaining questions were related to knowledge and expectations for the treatment of patients.

Permission for the study was obtained from the Bioethics Committee acting at the Nicolaus Copernicus University, Collegium Medicum in Bydgoszcz. 
Information obtained through the survey form was introduced into the STATISTICA 10 database. Pearson's $\chi^{2}$ independence test with dependence force ratio C - contingency (univariate analysis) was used for nominal analysis. The significance level of $p \leq 0.05$ was used. The relationship of two variables, one of which was an independent variable (gender, age, place of residence, education, marital status, physical conditions) and the second the dependent variable, was analyzed to evaluate the information obtained using the questionnaire.

\section{Results}

\section{Socio-demographic data}

Socio-demographic data was shown in Table 1.

Subjective assessment of knowledge about palliative chemotherapy and the independent variables

Seventy-seven percent of patients similarly reported having knowledge about palliative chemotherapy regardless of gender $(p=0.4)$, age $(p=0.2)$, place of residence $(p=0.1)$, and marital status $(p=0.5)$. There was a significant difference between the place of residence, education, financial situation, and subjective knowledge of palliative chemotherapy. People from large towns (population over 50 thousand), small towns, and villages responded that they have the knowledge ( $81 \%, 77 \%$ and $57 \%$, respectively, $p=0.05)$. All persons with higher education stated that they have the knowledge and $62.5 \%$ of patients with primary education level stated the same $(p=0.02) .90 .5 \%$ of patients with a very good financial situation reported that they are knowledgeable while $78 \%$ of patients with a good and $47 \%$ with a bad financial situation stated the same $(p=0.006)$.

Table 1. Socio-demographic data

\begin{tabular}{|c|c|c|}
\hline \multicolumn{2}{|c|}{ Socio-demographic data } & \multirow{2}{*}{$\begin{array}{c}n=\% \\
34\end{array}$} \\
\hline Sex & women & \\
\hline & men & 66 \\
\hline \multirow[t]{3}{*}{ Age } & $40-56$ & 22 \\
\hline & $57-70$ & 65 \\
\hline & $71-80$ & 13 \\
\hline \multirow{3}{*}{$\begin{array}{l}\text { Place of } \\
\text { residence }\end{array}$} & town $>50$ thousand & 60 \\
\hline & town $<50$ thousand & 26 \\
\hline & village & 14 \\
\hline \multirow[t]{4}{*}{ Education } & elementary & 32 \\
\hline & vocational & 19 \\
\hline & secondary & 30 \\
\hline & higher & 19 \\
\hline \multirow[t]{3}{*}{ Marital status } & single & 9 \\
\hline & married & 73 \\
\hline & divorced & 17 \\
\hline \multirow[t]{3}{*}{ Economic status } & very good & 21 \\
\hline & good & 64 \\
\hline & bad & 15 \\
\hline
\end{tabular}

Understanding the advisability of palliative chemotherapy to cure the disease and the independent variables

Knowledge about whether chemotherapy does affect the cure (possible answers: definitely yes, probably yes, it's hard to say, probably not, definitely not) did not depend on gender $(p=0.8)$, age $(p=0.9)$, place of residence $(p=0.7)$, marital status $(p=0.1)$ or education $(p=0.06)$. $41 \%$ of patients were convinced that the purpose of chemotherapy is to cure the disease. Inhabitants of large towns and small towns answered that the purpose of chemotherapy is to cure the cancer ( $40 \%$ and $46 \%$, respectively) more often than those living in rural areas (36\%) ( $p=0.03)$. Patients who described their economic status as good stated that the purpose of chemotherapy is to cure cancer more often than those with bad and very good economic status (48\%, $34 \%$ and $23 \%$, respectively) $(p=0.02)$.

Alleviating symptoms and improve quality of life by means of palliative chemotherapy and independent variables

Eighty-four percent of patients reported that the purpose of chemotherapy is to alleviate symptoms and improve quality of life regardless of gender $(p=0.4)$, age $(p=0.9)$ or marital status $(p=0.4)$. People living large towns claimed that chemotherapy is designed to ease the symptoms of disease and improve quality of life significantly more frequently than those living in villages and small towns (90\%, $79 \%$ and $73 \%$, respectively) ( $p=0.03)$. All persons with higher education and significantly fewer people with primary, vocational or secondary education thought that chemotherapy relieves symptoms and improves quality of life (84\%, 84\% and $73 \%$, respectively) ( $p=0.001$ ). People with very good economic status thought that chemotherapy relieves symptoms and improves quality of life more often than people with good and bad economic status ( $90 \%, 88 \%$ and $60 \%$, respectively) $(p=0.001)$.

\section{Usefulness of palliative chemotherapy in prolonging life and the independent variables}

Knowledge about the usefulness of chemotherapy in prolonging life did not depend on sex $(p=0.5)$, age $(p=$ $=0.3)$, education $(p=0.2)$, marital status $(p=0.6)$, or economic conditions $(p=0.3)$. Similarly, $84 \%$ of patients reported that chemotherapy prolongs life. Knowledge about whether palliative chemotherapy prolongs life depended on place of residence. With the increase in population (village, small town, large town) the number of people who claimed that chemotherapy prolongs their life increased (71\%, $77 \%$ and $90 \%$, respectively) ( $p=0.03)$.

\section{Stress and anxiety before the session of palliative chemotherapy and independent variables}

Stress and anxiety before a session of chemotherapy did not depend on gender $(p=0.3)$, age $(p=0.4)$, place of residence $(p=0.1)$, education ( $p=0.4)$, or marital status $(p=0.7)$. Similarly, $43 \%$ of respondents felt stress and anxiety before the session of chemotherapy, $49 \%$ of patients 
with good economic status, $47 \%$ with bad and $19 \%$ of patients with very good economic condition $(p=0.04)$.

Severity of stress and anxiety before the session of palliative chemotherapy and independent variables

The severity of stress and anxiety experienced by patients did not depend on sex $(p=0.6)$, age $(p=0.8)$, education $(p=0.1)$, marital status $(p=0.2)$, or economic status ( $p=0.7)$. Mild, moderate, and high levels of stress and anxiety were felt by $44 \%, 44 \%$ and $12 \%$ of patients, respectively. Mild stress was felt by $58 \%$ of patients living in large towns, $27 \%$ of patients living in small towns and $17 \%$ of patients living in rural areas $(p=0.005)$.

\section{Support from family, friends and acquaintances,} and the independent variables

Support from family, friends and acquaintances did not depend on gender $(p=0.9)$, age $(p=0.1)$, place of residence $(p=0.3)$, education ( $p=0.6)$, or economic status $(p=0.9) .83 \%$ of patients could rely on the support. All married patients (100\%) were able to rely on support, while divorced and single patients could not rely on support (65\% and $56 \%$, respectively) $(p=0.001)$.

Expectations from medical staff and the independent variables (patients could select more than one answer)

Expectations from medical staff did not depend on sex $(p=0.06)$, age $(p=0.2)$, place of residence $(p=0.4)$, education $(p=0.6)$, marital status $(p=0.07)$, or economic status ( $p=0.9$ ). Among the total of 225 answers, patients expected proper performance of medical procedures (33\%), factual information about palliative chemotherapy (27\%), care and patience (20\%), talking about their fears, desires, and needs (20\%).

\section{Expected general feeling after palliative} chemotherapy and independent variables

Sex $(p=0.9)$, age $(p=0.2)$, education $(p=0.2)$ and marital status ( $p=0.8$ ) did not affect the expected feeling after palliative chemotherapy. Sixty-four percent of patients expected that their feeling will not change after chemotherapy. The number of people who claimed that their feeling after chemotherapy will not change increased with the increase in population of their place of residence from $29 \%$ to $58 \%$ to $75 \%(p=0.001)$. Expected feeling after chemotherapy depended on economic status. People with poor, good and very good economic status believed that their feelings will improve (47\%, 25\% and 5\%, respectively) $(p=0.007)$.

Need for information about the treatment (stages of treatment, side effects of drugs) and life expectancy, and the independent variables (patients could select more than one answer)

There were no significant differences in expectations as to patients being informed about the treatment and life expectancy according to sex $(p=0.82)$, age $(p=0.5)$, place of residence ( $p=0.3$ ), education ( $p=0.7)$, marital status $(p=0.9)$, or economic status $(p=0.3)$. Sixty-nine percent of patients wanted to receive information about the treatment and $50 \%$ of patients wanted to obtain information about the length of their life.

\section{Need for assistance of a psychologist and the independent variables}

Nine people used help from a psychologist. Need for counseling did not depend on the age $(p=0.3)$, place of residence ( $p=0.07$ ), education ( $p=0.3$ ), or economic status ( $p=0.1$ ). 19\% of patients aged $40-56$ years and $15 \%$ of patients aged 57-70 years would benefit from counseling. Among the inhabitants of towns and villages $14 \%$ of patients would like to take advantage of a psychologist $(p=0.7)$. Patients with primary, vocational, secondary and higher education answered that they would like to use the help of a psychologist $(10 \%, 12.5 \%, 24 \%$, and $6 \%$, respectively) ( $p=0.3)$. There were differences between the need for assistance from a psychologist and marital status: $33 \%$ of divorced persons, $9 \%$ of married and $22 \%$ of singles indicated the need for assistance from a psychologist ( $p=$ $=0.04$ ). All people with very good economic status did not express the need for assistance from a psychologist, while $19 \%$ of patients with good and $14 \%$ with bad economic status did not want this type of assistance $(p=0.1)$.

\section{Discussion}

Chemotherapy plays an important role in the treatment of lung cancer, and it is used as a palliative treatment to prolong life, reduce discomfort resulting from emerging symptoms and consequently improve the quality of life [3].

In our study the majority of patients declared that they are knowledgeable about palliative chemotherapy. However, differences were found between the place of residence and subjective estimation of knowledge on the subject. These differences may be due to the fact that town dwellers are in close contact with the health care institutions and have better access to the Internet.

Almost half of respondents were often convinced that chemotherapy will cure them. In other studies it was observed that the majority of men and women have unrealistic expectations of palliative chemotherapy; they are more optimistic and believe in healing. Unrealistic expectations of chemotherapy may result from the lack of information provided by doctors on chemotherapy and/or putting thoughts out of their minds that chemotherapy may not lead to complete recovery. Doctors often do not take the effort to explain that their expectations are unrealistic. This is mostly due to the lack of appropriate skills in communicating bad news. Patients who receive care provided by an integrated network of medical institutions often provide the correct answers regarding the effectiveness of palliative chemotherapy. Patients who understand the purpose of treatment agree to palliative chemotherapy more often $[4,5]$.

The majority of patients stated that chemotherapy aims to alleviate symptoms and improve quality of life regardless of age, education, and economic status. In the 
case of others, all patients state that thanks to chemotherapy they feel better and they will live longer [5].

Stress and anxiety before a session of chemotherapy did not depend on sex, age, education or marital status. The results of other studies indicate that the severity of anxiety in both men and women at each stage of treatment is different. It was observed that this reaction on the day of drug admission in patients appeared more often in a significant degree. Women feel it at the level of a nuisance but men at a medium level. There was observed a significant relationship between sex and the presence and severity of anxiety during the third course of chemotherapy [6]. Other studies show significant differences between sex and the type of stress. All men report a lack of anxiety disorders. More than half of patients experiencing mild, moderate and severe anxiety are women [7]. This may result from the fact that women are more sensitive. Women often speculate about treatment, which leads to the increase of anxiety. There is a higher degree of severity of anxiety in women than in men [6]. Given the above, it is extremely important to provide psychological support, not only by medical personnel, but also by the family as well as in many cases by a psychologist.

Economic status and place of residence affected perceived stress. Similarly, other studies show that almost half of the patients living in small towns felt mild anxiety but moderate and severe fear was frequently perceived by the rural inhabitants [7]. More than half of retirees/ pensioners indicated that they felt strong stress. They often do not receive support from loved ones. Normal communication is difficult, especially because those close to the patient are usually powerless. They do not know that their presence with relatives is enough. The patient feels that she/he is not alone and it usually causes a sense of calm. The largest percentage of patients who were diagnosed with moderate and mild anxiety levels were employed. However, in another study moderate to severe anxiety was found to be experienced by people of working-class origin [7].

Representatives of both sexes could count on the same support regardless of age, education and economic status. Other studies have shown that patients under intensive therapy with chemotherapy receive a higher level of social support than patients at the stage of diagnosis, wherein the differences are not large [8]. Patients and relatives at the stage of diagnosis most frequently believe that cancer will not be detected. Of all socio-demographic factors only marital status had a significant impact on the support from family, friends and acquaintances. Other researchers have obtained similar results in this respect.

Lonely persons (divorced or widowed) have lower levels of social support compared with married persons or those having a life partner. In addition, almost all respondents indicate that in the fight against illness they had support from family and friends, regardless of the stage of treatment or marital status [9]. Undoubtedly, support has a significant impact on the overall functioning of the patient and consequently on the quality of life, and it is noted in the mental sphere mainly. This can lead to minimization of symptoms of the disease, anxiety in particular. It gives a sense of security, which is essential in terms of quality of life for patients struggling with cancer. It is found that a greater sense of helplessness exists more often in men than in women. Women have higher rates, especially at the level of social integration and greater confidence in transpersonal trust and to express optimism in life [10]

Both women and men awaited factual information about palliative chemotherapy, patience, care, the proper exercise of medical procedures, talking about their fears, desires and needs. The research carried out at the Center of Oncology in Warsaw shows that men and women expect more information than support, as in our study, while men report that they need more information about the disease and instrumental activities than support [11]. Patients determine the need for professional care and proximity to other persons as the most important [12].

In case of expectations related to the need for information on the stages of treatment, side effects of drugs and life expectancy, only half of the patients would like to obtain more information about treatment, but only half of them about life expectancy. Patients in life-threatening situations often apply the "ostrich" approach: they do not want to know or hear about a poor prognosis. However, in another study more than half of the respondents wanted to receive information on life expectancy [9].

Age, sex, education, place of residence and economic status did not affect the willingness to use the assistance of a psychologist, but only every third patient indicated this need. Patients are confident that they know how to overcome difficulties and crises using proven methods, most frequently. Patients are prone to denial and concealment of their emotions. It has been observed that people with secondary and higher education tend to prefer visiting a psychologist [9]. Other studies show that only every $10^{\text {th }}$ person has received counseling from a psychologist or psychiatrist. In addition, a similar number of people do not know where to go for advice, while most of the people who did not take the advice of a psychologist/psychiatrist say that they do not need it [9]. A more extensive comparison of our research to others was often difficult and sometimes even impossible because of the small number of publications on the subject. It is advisable to carry out further research because physicians' awareness of the desirability of palliative treatment using chemotherapy at the end of life and assessment of patients' expectations may contribute to changing attitudes in this respect. According to preliminary reports, we know that the use of chemotherapy within a few months before death is associated with deterioration of the quality of life, discomfort of caregivers/families and higher costs $[13,14]$.

In conclusion:

1. Knowledge of patients with lung cancer about palliative chemotherapy is insufficient. Almost half of them do not understand the purpose of treatment and hope that chemotherapy will cure them.

2. Most patients know that the purpose of chemotherapy is to alleviate symptoms, improve quality of life and prolong life.

3. Half of the patients want to obtain information on treatment and half of them about life expectancy. 
4. Almost half of the patients feel stress and anxiety about chemotherapy. Most of them do not use the help of a psychologist and do not feel the need for it.

The authors declare no conflict of interest.

\section{References}

1. Peppercorn JM, Smith TJ, Helft PR, et al. American society of clinical oncology statement: toward individualized care for patients with advanced cancer. J Clin Oncol 2011; 29: 755-60.

2. Kim A, Fall P, Wang D. Palliative care: optimizing quality of life. J Am Ostheopath Assoc 2005; 105: 9-15.

3. Pasek M, Dębska M. Interdyscyplinarna opieka nad pacjentem z chorobą nowotworową. In: Opieka nad pacjentem poddanym chemioterapii. Zaborowska A, Opasek M (eds.). Oficyna Wydawnicza AFM Krakowskie Towarzystwo Edukacyjne Sp. z o.o., Kraków 2011; 9-19.

4. Weeks JC, Catalano PJ, Cronin A. Patient's expectations about effect of chemotherapy for advanced cancer. N Engl J Med 2012; 367: 1616-25.

5. Temel JS, Greer JA, Adame S. Longitudinal perceptions of prognosis and goals of therapy in patients with metastatic non-small-cell lung cancer: results of a randomized study of early palliative care. J Clin Oncol 2011; 29: 2319-26.

6. Muraczyńska B, Zaczyk I. Subiektywna ocena reakcji emocjonalnych kobiet i mężczyzn w czasie trwania chemioterapii. In: Pacjent podmiotem troski zespołu terapeutycznego. Krajewska-Kułak E, Sierakowska M, Lewko J, Łukaszuk C. Białostocka Biblioteka Pielęgniarki i Położnej. Tom II, Białystok 2005.

7. Baczewska B, Kropornicka B, Drozd C, Olszak C. Ocena bólu, lęku i depresji u pacjentów hospitalizowanych z powodu choroby nowotworowej. In: Przedsiębiorczość i zarządzanie. Wybrane problemy organizacji i zarządzania w pielęgniarstwie. Pielęgniarstwo bez granic. Majchrzak-Kłokocka E, Seliga R (eds.). Spoteczna Akademia Nauk Tom XIV, zeszyt 10, część II. tódź 2013.

8. Zielińska-Więczkowska H, Betłakowski J. Pomiar i ocena wsparcia społecznego u pacjentów hospitalizowanych poddanych chemioterapii. Contemp Oncol (Pozn) 2010; 3: 229-32.

9. Grabińska K, Szewczyk-Cisek I, Hernik P, Mykała-Cieśla I, Kaziród D. Problemy i potrzeby psychosocjalne pacjentów poddanych chemioterapii onkologicznej. Psychoonkologia 2011; 2: 39-47.

10. Michałowska-Wieczorek I. Rola wsparcia w zmaganiu się z chorobą nowotworową. Psychoonkologia 2006; 2: 51-6.

11. Zieniuk AM. Oczekiwania pacjenta onkologicznego wobec personelu medycznego. Psychoonkologia 2009; 2: 17-27.

12. Czerwik M. Oczekiwania chorych z bólami nowotworowymi i stopień ich zaspokojenia w warunkach opieki paliatywnej. Probl Hig Epidemiol 2007; 88: 22-6.

13. Wright AA, Zhang B, Keating NL, Weeks JC, Prigerson HB. Associations between palliative chemotherapy and adult cancer patients and of life care and place of death: prospective cohort study. BMJ 2014; 348: 1219.

14. Mumm F. Palliative chemotherapy: no effects in end-of-life care? - The ultimate objective is to respect the patient's wishes. Ditsch Med Wochenschr 2014; 139: 766.

\section{Address for correspondence}

\section{Andrzej Nowicki}

Department of Oncology Nursing

Collegium Medicum in Bydgoszcz Techników 3

85-801 Bydgoszcz, Poland

e-mail: anow1_xl@wp.pl

Submitted: 20.04 .2015

Accepted: $\quad 20.07 .2015$ 